\title{
Picoplankton Community Composition by CARD-FISH and Flow Cytometric Techniques: A Preliminary Study in Central Adriatic Sea Water
}

\author{
Anita Manti, Paola Boi, Federica Semprucci, Rosaria Cataudella, and Stefano Papa \\ Department of Earth, Life and Environmental Sciences, University of Urbino "Carlo Bo" Via Ca' le Suore 2, 61029 Urbino, Italy \\ Correspondence should be addressed to Anita Manti, anita.manti@uniurb.it
}

Received 27 April 2012; Revised 13 June 2012; Accepted 22 June 2012

Academic Editor: Renzo Perissinotto

Copyright (C) 2012 Anita Manti et al. This is an open access article distributed under the Creative Commons Attribution License, which permits unrestricted use, distribution, and reproduction in any medium, provided the original work is properly cited.

\begin{abstract}
Data concerning picoplanktonic community composition and abundance in the Central Adriatic Sea are presented in an effort to improve the knowledge of bacterioplankton and autotrophic picoplankton and their seasonal changes. Flow cytometry analyses revealed the presence of two distinct bacteria populations: HNA and LNA cells. HNA cells showed an explicit correlation with viable and actively respiring cells. The study of viability and activity may increase our knowledge of the part that contributes really to the remineralization and bacterial biomass production. Authotrophic picoplankton abundance, especially picocyanobacteria, was strongly influenced by seasonality, indicating that light availability and water temperature are very important regulating factors. In terms of total carbon biomass, the main contribution came from heterotrophic bacteria with a lower contribution from autotrophic picoplankton. CARD-FISH evidenced, within the Eubacteria domain, the dominance of members of the phyla Alphaproteobacteria, with a strong contribution from SAR11clade, followed by Cytophaga-Flavobacterium and Gammaproteobacteria. The bacterial groups detected contributed differently depending when the sample was taken, suggesting possible seasonal patterns. This study documents for the first time picoplankton community composition in the Central Adriatic Sea using two different approaches, FCM and CARD-FISH, and could provide preliminary data for future studies.
\end{abstract}

\section{Introduction}

Knowledge of seawater microbial diversity is important in order to understand their community structure and pattern of distribution. In the ocean water column, organisms $<200 \mu \mathrm{m}$ include a variety of taxa: free viruses, autotrophic bacteria (cyanobacteria, which include the group formerly known as prochlorophytes), heterotrophic bacteria, protozoa (flagellates and ciliates), and small metazoans [1] with different morphological, ecological, and physiological characteristics. Autotrophs and heterotrophs constitute two fundamental functional units in ecosystems: the first generally dominate eutrophic systems while heterotrophs generally dominate oligotrophic systems $[2,3]$.

Among these taxa, autotrophic and heterotrophic picoplankton can play an important role in the functioning of the microbial loop [4], with the former regarded as important templates of assimilable carbon biomass at the base of the microbial food web [5], while the latter acts as both remineralizers of organic carbon and trophic intermediaries within aquatic ecosystems $[3,6]$. These represent an important source of food for a variety of marine organisms [7]. Changes in environmental factors such as temperature and inorganic nutrients are known to control the presence and distribution of specific autotrophic populations and specific bacterial groups. Thus, the accurate determination of picoplankton abundance, biomass, and activity is essential for understanding the aquatic ecosystem.

For several decades epifluorescence microscopy counts have been the standard method for determining bacterial abundance in plankton samples.

Total microscopic count methods are relatively fast, but limitations of these techniques include time consuming, subjectiveness linked to the operator and the inability to discriminate between living and dead bacteria. To overcome this limit, direct viable counts (DVCs), allowing bacterial growth 
without division, have been applied in many autoecological studies. These permit the detection of viable cells, but its application to natural samples suffers from methodological limitations ([8] and the references within).

Viable But No Culturable Cells (VBNCs) are normally difficult to detect. It is well known that $>999 \%$ of the bacterioplankton community in seawater cannot be cultured on Marine Agar 2216. The study of marine bacteria has strongly advanced with the introduction of molecular techniques $[9,10]$. Different culture-independent approaches based on ribosomol RNA (rRNA) nucleotide sequences have been developed and used to study the diversity of marine bacterioplankton communities [11, 12]. Fluorescent In situ hybridization (FISH) for bacteria was described more than twenty years ago [13] and became the method of choice for the rapid detection and identification of microorganisms in natural ecosystems (e.g., $[14,15])$.

Due to the low RNA content of marine bacteria, many attempts have been made to enhance the sensitivity of FISH. One example of application is the catalysed reporter deposition (CARD), introduced in 1989 by Bobrow et al. [16], also known as tyramide signal amplification (TSA). CARD is an enzyme-mediated detection method based on the deposition of a high number of tyramide molecules (tyramine molecules labelled with a fluorochrome) by peroxidase catalytic activity. The combination of FISH with CARD (CARD-FISH) has been proposed as a more sensitive technique for microbial community analysis (e.g., $[17,18]$ ).

On the other hand, flow cytometry (FCM) is a useful tool for counting and identifying microorganisms, offering the prospect of real-time microbial analysis of individual cells, assessing their viability and allowing physical separation of particular bacterial populations and cell sorting for further analysis [19]. Flow cytometry has been routinely used for the analysis of different types of microorganisms in marine samples in the past [20], and it is now commonly accepted as a reference technique in oceanography $[21,22]$.

In the present study, data were collected each month for one year with the following objectives to give a preliminary description of the bacterial community composition and diversity in the Central Adriatic Sea using different techniques such as CARD-FISH and FCM and to observe autotrophic and heterotrophic picoplankton seasonal changes.

\section{Materials and Methods}

2.1. Study Area. The Adriatic sea has diverse trophic conditions; the shallow northern basin is a productive system and the deeper central and southern basins are oligotrophic. The northern region, characterized by a high primary productivity, is influenced by the presence of the Po River and other smaller rivers providing nutrients [23]. The middle and southern regions are characterized by a lower primary productivity with the exception of the western coastal areas which are enriched by the southward coastal current from the northern basin. The general circulation is cyclonic with subbasin gyres (permanent or seasonal) interconnected by coastal currents and jets [24].

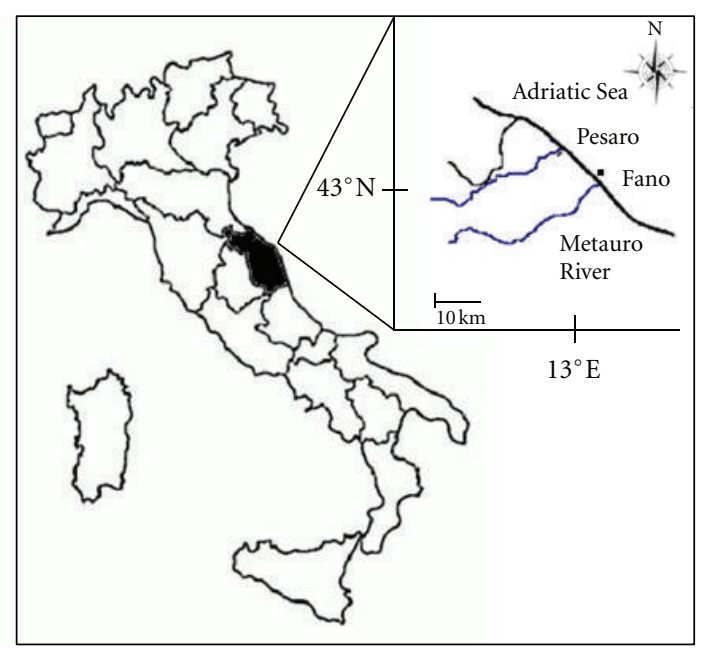

Figure 1: Location of the study area.

A sampling station off the central Adriatic coast $\left(43^{\circ} 49^{\prime} \mathrm{N} ; 13^{\circ} 03^{\prime} \mathrm{EO}\right)$ was chosen as the area of study for this work (Figure 1). The site is located in front of a gravel beach and is characterized by tourist charge and beach establishments as the main pollution sources during summertime.

Samples were collected monthly from December 2006 to November 2007; replicates $(n=3)$ were immediately fixed (for CARD-FISH) or processed (for FCM) upon arrival in the laboratory.

The physical-chemical parameters (water temperature, $\mathrm{pH}$, salinity, electrical conductivity) were measured in situ using a multiparametric probe.

2.2. Flow Cytometric Analyses. Flow cytometric analyses were performed by flow cytometry with a FACScalibur (Becton Dickinson, USA) equipped with an Argon Laser set at $15 \mathrm{mV}$ and tuned to an excitation wavelength $(488 \mathrm{~nm})$. Multiparametric analysis was performed on both scattering signals (FSC, SSC) and FL1 green fluorescence, 530/30), FL2 (orange fluorescence, 585/42), FL3 (red fluorescence, $>670$ ). Fluorochromes with a high affinity for nucleic acids as SYBR Green I (Molecular Probes, Inc., Eugene, Oregon, U.S.A.) and Propidium Iodide (PI, Sigma-Aldrich Corp. St. Louis, MO, USA.) were used to stain bacterial cells for the cytometric analysis; SYBR Green I was used to determine heterotrophic bacteria concentration [25] and Nucleic Acid Double Staining (NADS) protocol to analyse viability cells $[26,27]$. Cell debris was excluded from acquisition analysis by a sample-specific FL1 threshold. To measure actively respiring bacteria, tetrazolium salt 5-cyano-2,3ditolytetrazolium chloride (CTC, Polysciences Inc., USA) was used at a final concentration of $5 \mathrm{mM}$ [28]. The assessment of autofluorescence that was performed by combining the fluorescence conferred to microorganisms, due to the presence of fluorescence pigmentation (detectable with FL2 or FL3 channels), with the morphological data obtained by light scatter signals. Thresholding was carried out using the red channel. 
TABLE 1: Oligonucleotide probes used in the present study.

\begin{tabular}{|c|c|c|c|c|}
\hline Probe & $5^{\prime}-\ldots \ldots \ldots \ldots \ldots \ldots \ldots-3^{\prime}$ & $\% \mathrm{FA}\left(35^{\circ} \mathrm{C}\right)$ & Target & Reference \\
\hline Eub338 & 5'-GCTGCCTCCCGTAGGAGT-3' $^{\prime}$ & 55 & Most Eubacteria & [36] \\
\hline Eub338 II & $5^{\prime}$-GCAGCCACCCGTAGGTGT-3' & 55 & Planctomycetales & [37] \\
\hline Eub338 III & $5^{\prime}$-GCTGCCACCCGTAGGTGT-3' & 55 & Verrucmicrobia & [37] \\
\hline Alf968 & 5'-GGTAAGGTTCTGCGCGTT-3' & 45 & Alphaproteobacteria & [38] \\
\hline Gam42a & 5'-GCCTTCCCACATCGTTT-3' & 55 & Gammaproteobacteria & [39] \\
\hline Bet $42 a$ (comp. for Gam42a) & 5'-GCCTTCCCACTTCGTTT-3' & 55 & Betaproteobacteria & {$[39]$} \\
\hline CF319a & 5'-TGGTCCGTGTCTCAGTAC-3' & 55 & Cytophaga flavobacterium & [39] \\
\hline Sar11 & 5'-TACAGTCATTTTCTTCCCCGAC-3' & 45 & Sar11clade & {$[40]$} \\
\hline Non338 & 5'-ACTCCTACGGGAGGCAGC-3' & 20 & Nonsense control & [36] \\
\hline
\end{tabular}

Before processing samples for flow analyses, Cytocount Counting beads (DakoCytomation, Denmark) were added to the stained samples and setup, and calibration procedures were optimized for the absolute counting protocols [29]. All data were statistically analysed with CellQuest software.

2.3. Carbon Cell Conversion. Conversion factors from the literature were used to estimate carbon biomass: $115 \mathrm{fg} C$ cell-1 for picocyanobacteria [30], $1500 \mathrm{fg} \mathrm{C}$ cell- 1 for picoeuaryotes [31], and $20 \mathrm{fg} \mathrm{C}$ cell-1 for heterotrophic bacteria $[32,33]$.

2.4. Card Fish. The samples were collected and immediately fixed with paraformaldehyde ( $2 \%$ final concentration), incubated for 24 hours at $4^{\circ} \mathrm{C}$, and filtered onto $0.22 \mu \mathrm{m}$ polycarbonate membranes. The bacterial cells were permeabilized with both lysozyme solution [18] and achromopeptidase, as previously described [34].

Cells on filter sections were hybridized with one domain-specific probe EUB338 (specific for Eubacteria) and five group-specific probes, EUB338II (specific for Planctomycetales), EUB338III (specific for Verrucomi-crobiales), ALF968 (for Alphaproteobacteria), GAM42a (for Gammaproteobacteria), CF319a (for Cytophaga-FlavobacteriumBacteroidetes), one subgroup-specific probe, SAR11, and the negative control NON338 (nonsense probe). The unlabelled competitors BET42a for GAM42a and GAM42a for BET42a were used. Oligonucleotide probes modified at the $5^{\prime}$ end with HRP were synthesized by Biomers, Germany.

Hybridization, counterstaining with 4,6-diamidino-2phenylindole (DAPI, Molecular Probes, Inc., Eugene, USA, $1 \mu \mathrm{g} / \mathrm{mL}$ ) and mounting for microscopic evaluation were performed as described previously [35]. The probe sequences and formamide concentrations used are given in Table 1.

The slides were examined with an LED fluorescence microscope (Fraen Corporation S.r.l., Milano, Italy), and microscopic counts of hybridized and DAPI-stained cells were produced using 900x magnification (15x ocular and 60x objective lenses). Three parallel sample preparations were counted for each probe, and between 20 and 40 fields were considered on each sample slide. Only free-living bacteria were counted. The counting results were corrected for background fluorescence by subtracting the signals given off by the NON338 probe.
2.5. Statistical Analyses. Possible differences in the seasonal variation of heterotrophic and autotrophic picoplankton were evaluated using the analysis of variance (ANOVA) (SPSS v.19 program). Principal component analysis (PCA) was carried out on environmental data in order to visualise the trend of the main abiotic variables. The biological parameters were projected on the factor plane as additional variables, without contributing to the results of the analysis. This can provide an insight into the possible influence of environmental variables on each biological variable (STATISTICA v.8 computer program).

\section{Results and Discussion}

Surface waters during the sample period were characterized by a temperature ranging from $8.9^{\circ} \mathrm{C}$ to $24.9^{\circ} \mathrm{C}, \mathrm{pH}$ varied from 8.0 to 8.2 and conductivity from 47.9 to $55.7 \mathrm{mS} / \mathrm{cm}$.

The sampling site showed salinities in the range of 30.3 to $37.0 \%$, with the lowest value in March probably due to intensive rains in that period.

Flow cytometric data provided information on the picoplankton populations in the sampling site (Figure 2). As far as heterotrophic bacteria were concerned, concentrations ranged from $1.03 E+06$ to $2.73 E+06 \mathrm{cell} / \mathrm{mL}$ (Figure 3). These values were similar to those obtained at the same site during the 2005 late spring-summer period (unpublished data).

Furthermore, cytometric analyses of fluorescence (FL1) and morphological parameters (SSC) revealed the presence of two distinct bacteria populations: HNA (High NucleicAcid) and LNA (Low Nucleic-Acid) cells (Figure 2(a)), as previously reported by other researchers [41]. These populations are widespread across many different aquatic ecosystems and environmental gradients, and they can be detected independently of the protocol used [41]. They are the result of complex processes which involve both the passage of cells from one fraction to another, as well as bacterial groups that are characteristic of either HNA or LNA. In our samples HNA cells, ranging from $64 \%$ to $85 \%$, are always more abundant than LNA cells.

An ANOVA test indicates significant differences of total $(P<0.001)$ and viable cells $(P<0.05)$ during the sampling period. Data concerning viability (Figure $2(\mathrm{~b})$ ) showed that viable cell mean values were quite high (mean value 70\%) except in January, September, and April 


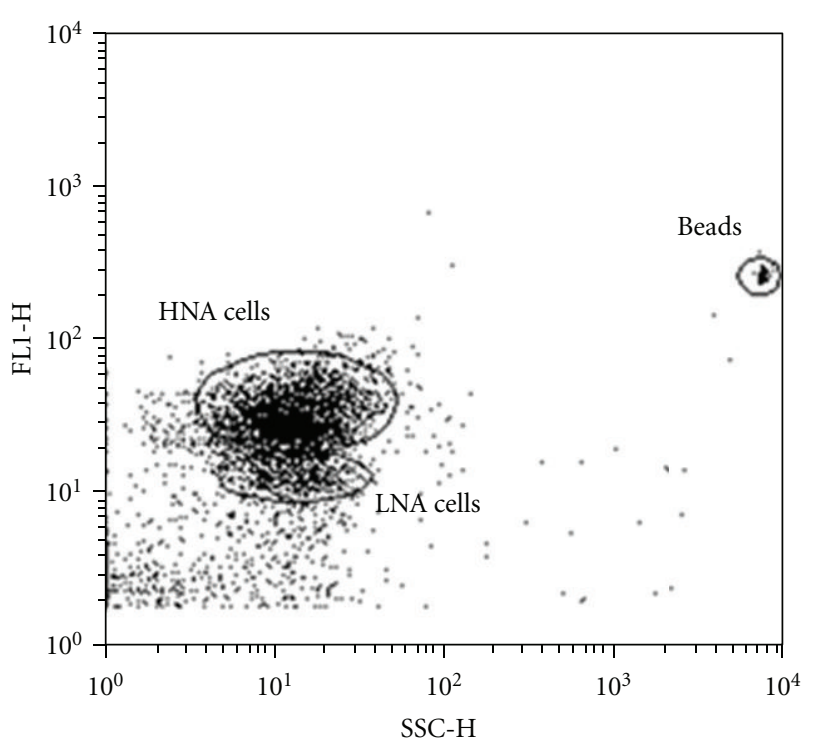

(a)

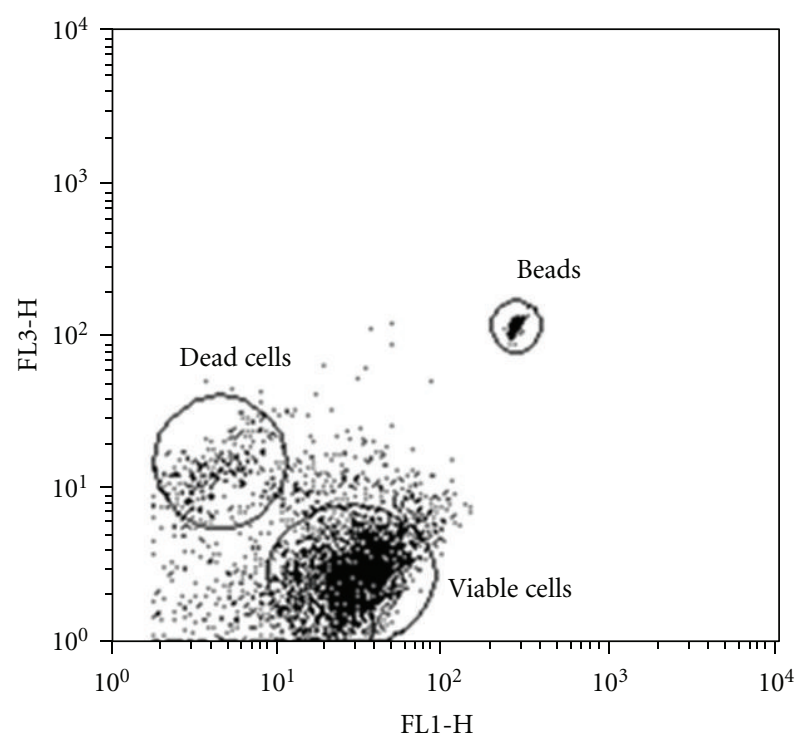

(b)

FIGURE 2: Examples of dot plot showing bacteria population (HNA and LNA cells) stained with SYBR Green I (a); viable and dead cells stained with SYBR Green I and PI (b).

$(6.74 E+05 \mathrm{cell} / \mathrm{mL}, 6.84 E+05 \mathrm{cell} / \mathrm{mL}$ and $8.20 E+05 \mathrm{cell} / \mathrm{mL}$, resp.) where we registered the lowest values. A similar trend was also shown by total bacteria cells, except in August where a decrease of viable cells corresponded to an increase in total cells (Figure 3).

Viable cell values are similar to those obtained by Grégori et al. [27] off the north-western Mediterranean coast. The study of viable fraction is important because this is the component that really contributes to the remineralization and bacterial biomass production.

Actively respiring bacteria (CTC+) are reported as a percentage of the total cell concentration.

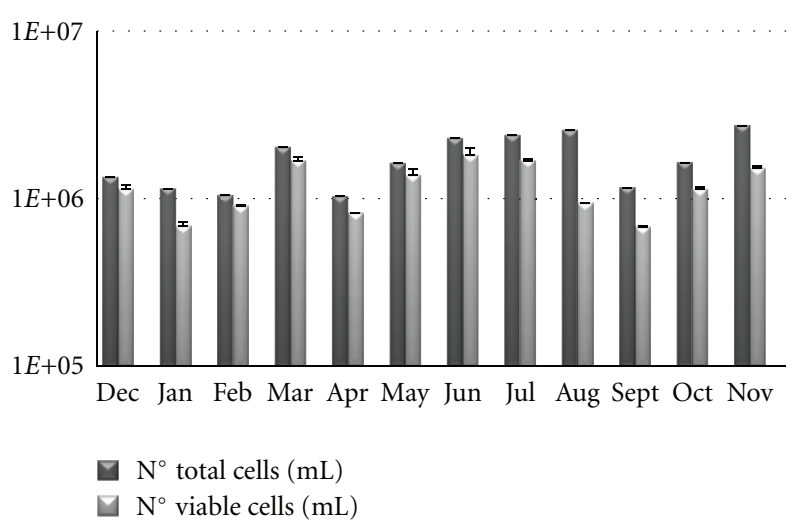

Figure 3: Total and viable bacterioplankton cell counts $( \pm$ SD of 3 replicates) measured by FCM from December 2006 to November 2007.

While the use of this method has increased over the last few years, there have also been a number of studies that are highly critical of CTC as a means of distinguishing metabolically active cells ([42] and references therein), suggesting that growth rates scaled to the number of CTC+ cells should be interpreted with caution [43].

Some fraction of active cells is probably not detected by the CTC method, with the proportion of total cells positive to CTC being low at less than $20 \%$ or even much less [42]. On the other hand, the relatively strong correlation between bacterial production and the number of respiring cells reported by other authors [43], suggests that the CTC method accurately measures the activity of bacterioplankton cells, and the pattern is probably still valid.

In our samples, CTC-positive cells ranged from 1 to $19 \%$ in the sampling period. These results are similar to those obtained by Gasol et al. [28] in the north-western Mediterranean.

Furthermore, the abundance of actively respiring bacteria was also positively correlated with total, cells, as previously reported in lakes [43] and in coastal waters [44] and with viable cells and HNA cells. These findings seem to evidence the presence of viable and actively respiring cells within HNA fraction rather than in LNA fraction.

Two populations of autotrophic picoplankton were detected by FCM analysis: (1) cyanobacteria are characterised by cells which emit an orange fluorescence (phycoerythrin) and a red fluorescence (chlorophyll); (2) picoeukaryotes only emit a red fluorescence $[45,46]$.

An ANOVA test indicates significant differences in picocyanobacteria $(P<0.001)$ and picoeukaryotes $(P<0.01)$ counts during the sampling period.

Picocyanobacteria were always more abundant than picoeukaryotes with values ranging from $7.42 E+03$ cell $/ \mathrm{mL}$ and $8.23 E+04 \mathrm{cell} / \mathrm{mL}$ (Figure 4), falling within a range of values already reported for the Northern Adriatic Sea [47] and the Southern Adriatic sea [48].

The abundance of picophytoplankton and heterotrophic bacteria measured in this study is comparable to the results 


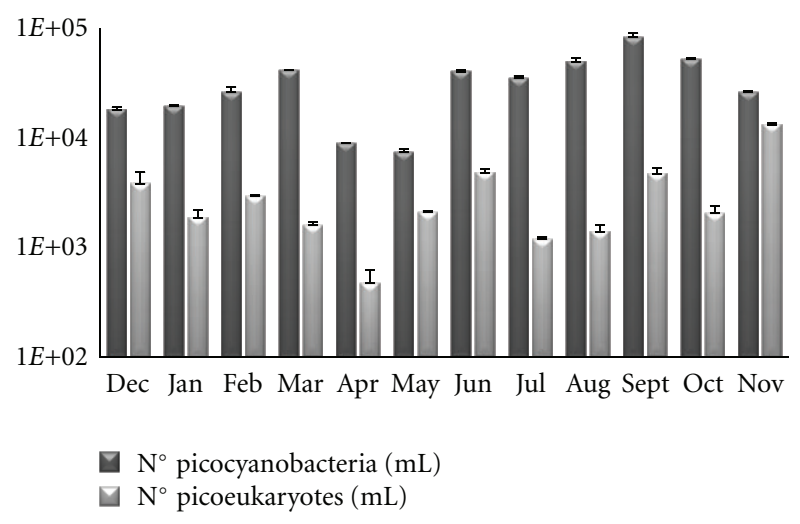

Figure 4: Picocyanobacteria and picoeukaryotes cell counts $( \pm \mathrm{SD}$ of 3 replicates) measured by FCM from December 2006 to November 2007.

of earlier studies, even if under different trophic conditions $[30,31,49,50]$.

PCA was used to visualize the trends of biological variables in relation to the environmental variables measured at the sampling site (Figures 5 and 6). Two principal components were identified that together explained 95\% of the data variance. Freshwater inputs (PC1) (due to riverine discharge and coastal run-off) explained 55\% of the variance and was primarily affected by salinity and conductivity and to a lesser extent by temperature and pH. Seasonality (PC2) explained $40 \%$ of the variance and was mainly affected by temperature and $\mathrm{pH}$. Viable cells and LNA appeared to follow a decrease in salinity and conductivity, while picocyanobacteria followed increases in these environmental parameters. HNA and total bacteria increased with temperature, followed by viable cells, CTC+, and picocyanobacteria. Picoeukaryotes were poorly affected by both factors. With increasing water temperature, there is an increase in picocyanobacteria, indicating that temperature is a more important regulating factor for picophytoplankton, as previously observed in other studies $[47,51]$.

The main contribution to total carbon biomass, obtained using the conversion factors, came from heterotrophic bacteria with a mean value of $35 \mathrm{mg} \mathrm{C} / \mathrm{m}^{3}$. The contribution of autotrophic bacteria (mean value $9 \mathrm{mg} \mathrm{C} / \mathrm{m}^{3}$ ) is only from picocyanobacteria and picoeukaryotes. This, together with greater heterotrophic pressure, could explain the difference observed between these two functional groups. Furthermore, picoeukaryotes surpass picocyanobacteria in terms of biomass as previously described by Zubkov et al. [31].

3.1. Card Fish. Microscopic DAPI-stained cell counts were in some cases quite difficult to obtain because of the amount of organic and inorganic compounds present in the filters. All samples examined showed bright hybridization signals with a good distinction between probe-specific signals and the background, although cells in some samples showed a bright outline. We thought it could be a problem of endogenous peroxidases [35], but the test was negative in all samples. Another possibility was that permeabilization was

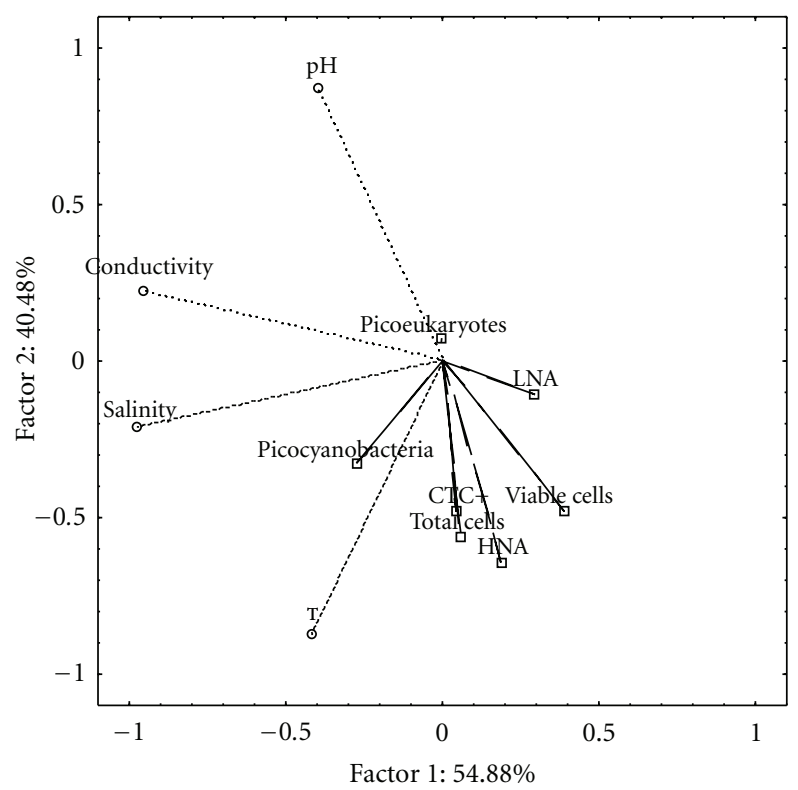

$\circ$ Active
$\square$ Suppl.

FIGURE 5: PCA ordination diagram of sampling based on the selected variables.

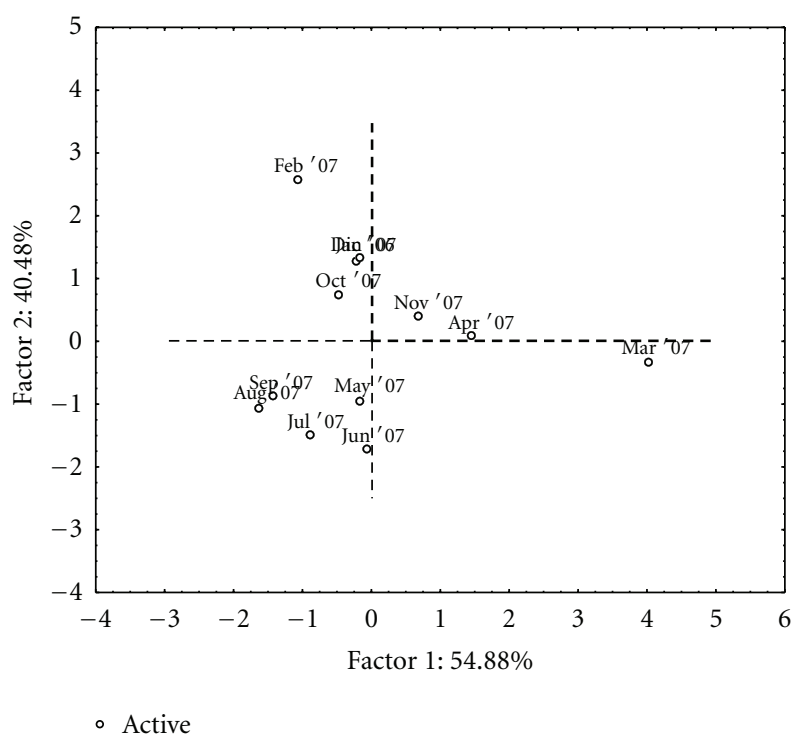

FIgURE 6: Scatter diagram plotting factors 1 and 2 of sampling stations.

too strong, but the application of different incubation times and concentrations did not produce different results. The negative control (nonsense probe NON338), used to detect cells that were not specifically stained, was below $1 \%$ of total DAPI stained cells in all samples.

The microbial communities analysed were dominated by Eubacteria (probe EUB338I-III). In fact detection yields relative to the EUB338 probe in respect to DAPI ranged from $55 \pm 2 \%$ to $92 \pm 4 \%$ (data not shown). Previous findings 
showed that EUB338 hybridizing cells ranged from 31-71\% of DAPI-stained cells for pelagic bacteria from the North Sea [52] and from 39\% to $96 \%$ in the Antarctic Ocean [53].

CARD-FISH counts evidenced the dominance of members of the phyla Alphaproteobacteria, with a strong contribution from SAR11, followed by Cytophaga-flavobacterium and Gammaproteobacteria. Data on Gammaproteobacteria are in accordance with those obtained by Glöckner et al. [15] for pelagic bacteria, where the contribution of Gammaproteobacteria was $13 \%$ of total bacteria. Similar values for members of Gammaproteobacteria were also registered by Glöckner et al. [15], with maximum values of 9\%. Findings from a more recent paper [54] showed lower abundances of gamma proteobacteria (except for July sampling) ranging from $2 \%$ to $8 \%$ in north-western Mediterranean coastal waters.

Bacterioplankton composition differed each month. In fact, bacterial groups contributed differently depending on sampling time, suggesting possible seasonal patterns.

With relative abundances of $44 \pm 3 \%$, SAR11 was the most abundant phylum in March, while in December Alf968 (less the SAR11 contribution) had the maximum value with $33 \pm 5 \%$ (Figure 7). Overall, except for December, we could assign the majority of Alphaproteobacteria to the SAR11 clade, which is typical of oligotrophic open ocean waters [30].

The genus Cytophaga-Flavobacterium, detected by the CF319a probe, is known to constitute a substantial fraction of coastal marine communities, and the specificity of this probe has recently been evaluated [55]. It covers $90 \%$ of the 16SrRNA sequences of the Flavobacteria and Sphingobacteria classes, but also detects some members of the Bacteroidia class and some sequences outside this phylum [56]. In the June samples, probe CF319a detected about one-fourth of the total bacterioplankton compared to the EUB338 I, II, and III probes. High abundances of CF319a-positive cells have already been shown in other coastal marine sites, and have been linked to algal blooms and higher substrate concentrations (see [56] and the references within).

\section{Conclusions}

The aim of this work was to preliminarily describe picoplankton community composition in a station localized off the central Adriatic coast.

Seasonal changes of the relative abundance of main bacterial groups were observed during the monitoring period. This could be due to the fact that aquatic bacteria in coastal waters distribute themselves in different ways depending on particular seasons: some bacteria may in fact be motile during particular conditions linked to substrate viability and patchiness [57].

Viable cell analyses revealed a clear correlation with HNA fraction and actively respiring cells. They represent the really active component, so their study is fundamental to better understanding changes in biogeochemical cycles.

Autotrophs, and in particular picocyanobacteria, are strongly linked to light availability, thus showing their maximum concentration during the summer period.

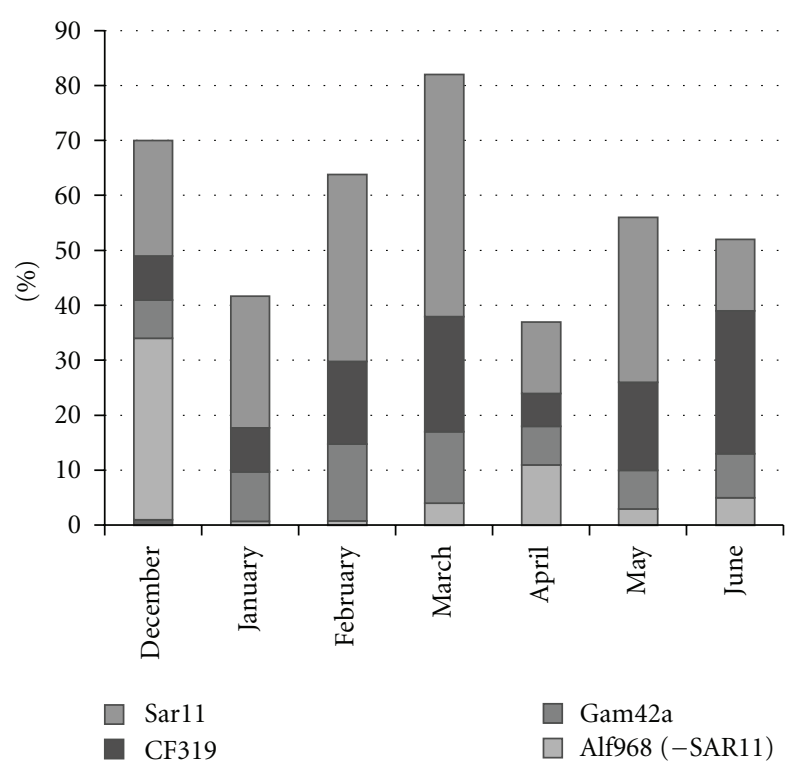

FIGURE 7: Bacterioplankton community composition expressed as percentages respect to EUB during the sampling period.

Even if it is a preliminary study, it is, to our knowledge, the first study in the Central Adriatic Sea using two different approaches, such as FCM and CARD-FISH. Future investigations are needed in order to enhance knowledge of bacterioplankton composition and autotrophic communities. It would also be interesting to evaluate seasonal variations in the relative abundance of bacteria populations at a lower phylogenetic level, using species-specific probes. Such studies are needed considering the importance of picoplankton as a potential sentinel of global climate changes.

\section{References}

[1] L. Legendre, C. Courties, and M. Troussellier, "Flow cytometry in oceanography 1989-1999: environmental challenges and research trends," Cytometry, vol. 44, no. 3, pp. 164-172, 2001.

[2] Q. Dortch and T. T. Packard, "Differences in biomass structure between oligotrophic and eutrophic marine ecosystems," Deep Sea Research A, vol. 36, no. 2, pp. 223-240, 1989.

[3] J. M. Gasol, P. A. del Giorgio, and C. M. Duarte, "Biomass distribution in marine planktonic communities," Limnology and Oceanography, vol. 42, no. 6, pp. 1353-1363, 1997.

[4] J. Porter, D. Deere, M. Hardman, C. Edwards, and R. Pickup, "Go with the flow-use of flow cytometry in environmental microbiology," FEMS Microbiology Ecology, vol. 24, no. 2, pp. 93-101, 1997.

[5] C. Callieri and J. G. Stockner, "Freshwater autotrophic picoplankton: a review," Journal of Limnology, vol. 61, no. 1, pp. $1-14,2002$.

[6] T. Fenchel, "Marine plankton food chains," Annual Review of Ecology and Systematics, vol. 19, pp. 19-38, 1988.

[7] S. Das, P. S. Lyla, and S. A. Khan, "Marine microbial diversity and ecology: importance and future perspectives," Current Science, vol. 90, no. 10, pp. 1325-1335, 2006.

[8] F. Joux and P. Lebaron, "Ecological implications of an improved direct viable count method for aquatic bacteria," 
Applied and Environmental Microbiology, vol. 63, no. 9, pp. 3643-3647, 1997.

[9] C. Pedròs-Aliò, "Diversity of bacterioplankton," Trends in Ecology \& Evolution, vol. 8, no. 3, pp. 86-90, 1993.

[10] R. I. Amann, W. Ludwig, and K. H. Schleifer, "Phylogenetic identification and in situ detection of individual microbial cells without cultivation," Microbiological Reviews, vol. 59, no. 1, pp. 143-169, 1995.

[11] T. D. Mullins, T. B. Britschgi, R. L. Krest, and S. J. Giovannoni, "Genetic comparisons reveal the same unknown bacterial lineages in Atlantic and Pacific bacterioplankton communities," Limnology and Oceanography, vol. 40, no. 1, pp. 148-158, 1995.

[12] M. Schauer, V. Balagué, C. Pedròs-Aliò, and R. Massana, "Seasonal changes in the taxonomic composition of bacterioplankton in a coastal oligotrophic system," Aquatic Microbial Ecology, vol. 31, no. 2, pp. 163-174, 2003.

[13] R. I. Amann, L. Krumholz, and D. A. Stahl, "Fluorescent-oligonucleotide probing of whole cells for determinative, phylogenetic, and environmental studies in microbiology," Journal of Bacteriology, vol. 172, no. 2, pp. 762-770, 1990.

[14] R. Amann and W. Ludwig, "Ribosomal RNA-targeted nucleic acid probes for studies in microbial ecology," FEMS Microbiology Reviews, vol. 24, no. 5, pp. 555-565, 2000.

[15] F. O. Glöckner, B. M. Fuchs, and R. Amann, "Bacterioplankton compositions of lakes and oceans: a first comparison based on fluorescence in situ hybridization," Applied and Environmental Microbiology, vol. 65, no. 8, pp. 3721-3726, 1999.

[16] M. N. Bobrow, T. D. Harris, K. J. Shaughnessy, and G. J. Litt, "Catalyzed reporter deposition, a novel method of signal amplification-application to immunoassays," Journal of Immunological Methods, vol. 125, no. 1-2, pp. 279-285, 1989.

[17] H. M. J. Kerstens, P. J. Poddighe, and A. G. J. M. Hanselaar, "A novel in situ hybridization signal amplification method based on the deposition of biotinylated tyramine," Journal of Histochemistry and Cytochemistry, vol. 43, no. 4, pp. 347-352, 1995.

[18] A. Pernthaler, J. Pernthaler, and R. Amann, "Fluorescence in situ hybridization and catalyzed reporter deposition for the identification of marine bacteria," Applied and Environmental Microbiology, vol. 68, no. 6, pp. 3094-3101, 2002.

[19] E. L. Joachimsthal, V. Ivanov, J. H. Tay, and S. T. L. Tay, "Flow cytometry and conventional enumeration of microorganisms in ships' ballast water and marine samples," Marine Pollution Bulletin, vol. 46, no. 3, pp. 308-313, 2003.

[20] J. Vives-Rego, P. Lebaron, and G. Nebe-von Caron, "Current and future applications of flow cytometry in aquatic microbiology," FEMS Microbiology Reviews, vol. 24, no. 4, pp. 429448, 2000.

[21] C. S. Yentsch and C. M. Yentsch, "Single cell analysis in biological oceanography and its evolutionary implications," Journal of Plankton Research, vol. 30, no. 2, pp. 107-117, 2008.

[22] A. Manti, S. Papa, and P. Boi, "What flow cytometry can tell us about marine micro-organisms-current status and future applications," in Flow Cytometry-Recent Perspectives, I. Schmid, Ed., pp. 1-28, InTech, 2012.

[23] M. Zavatarelli, J. W. Baretta, J. G. Baretta-Bekker, and N. Pinardi, "The dynamics of the Adriatic Sea ecosystem. An idealized model study," Deep-Sea Research I, vol. 47, no. 5, pp. 937-970, 2000.

[24] A. Artegiani, D. Bregant, E. Paschini, N. Pinardi, F. Raicich, and A. Russo, "The Adriatic Sea general circulation. Part II: baroclinic circulation structure," Journal of Physical Oceanography, vol. 27, no. 8, pp. 1515-1532, 1997.
[25] D. Marie, F. Partensky, S. Jacquet, and D. Vaulot, "Enumeration and cell cycle analysis of natural populations of marine picoplankton by flow cytometry using the nucleic acid stain SYBR Green I," Applied and Environmental Microbiology, vol. 63, no. 1, pp. 186-193, 1997.

[26] S. Barbesti, S. Citterio, M. Labra, M. D. Baroni, M. G. Neri, and S. Sgorbati, "Two and three-color fluorescence flow cytometric analysis of immunoidentified viable bacteria," Cytometry, vol. 40, no. 3, pp. 214-218, 2000.

[27] G. Grégori, S. Citterio, A. Ghiani et al., "Resolution of viable and membrane-compromised bacteria in freshwater and marine waters based on analytical flow cytometry and nucleic acid double staining," Applied and Environmental Microbiology, vol. 67, no. 10, pp. 4662-4670, 2001.

[28] J. M. Gasol, P. A. del Giorgio, R. Massana, and C. M. Duarte, "Active versus inactive bacteria: size-dependence in a coastal marine plankton community," Marine Ecology Progress Series, vol. 128, no. 1-3, pp. 91-97, 1995.

[29] A. Manti, P. Boi, T. Falcioni et al., "Bacterial cell monitoring in wastewater treatment plants by flow cytometry," Water Environment Research, vol. 80, no. 4, pp. 346-354, 2008.

[30] W. K. W. Li and W. G. Harrison, "Chlorophyll, bacteria and picophytoplankton in ecological provinces of the North Atlantic," Deep-Sea Research II, vol. 48, no. 10, pp. 2271-2293, 2001.

[31] M. V. Zubkov, M. A. Sleigh, G. A. Tarran, P. H. Burkill, and R. J. G. Leakey, "Picoplanktonic community structure on an Atlantic transect from $50^{\circ} \mathrm{N}$ to $50^{\circ} \mathrm{S}$," Deep-Sea Research I, vol. 45, no. 8, pp. 1339-1355, 1998.

[32] S. Lee and J. A. Fuhrman, "Relationships between biovolume and biomass of naturally derived marine bacterioplankton," Applied and Environmental Microbiology, vol. 53, no. 6, pp. 1298-1303, 1987.

[33] L. A. Pan, J. Zhang, and L. H. Zhang, "Picophytoplankton, nanophytoplankton, heterotrohpic bacteria and viruses in the Changjiang Estuary and adjacent coastal waters," Journal of Plankton Research, vol. 29, no. 2, pp. 187-197, 2007.

[34] R. Sekar, A. Pernthaler, J. Pernthaler, F. Warnecke, T. Posch, and R. Amann, "An improved protocol for quantification of freshwater Actinobacteria by fluorescence in situ hybridization," Applied and Environmental Microbiology, vol. 69, no. 5, pp. 2928-2935, 2003.

[35] A. Pernthaler, J. Pernthaler, and R. Amann, "Sensitive multicolor fluorescence in situ hybridization for the identification of environmental microorganisms," in Molecular Microbial Ecology Manual, 3, pp. 711-726, 2nd edition, 2004.

[36] R. I. Amann, B. J. Binder, R. J. Olson, S. W. Chisholm, R. Devereux, and D. A. Stahl, "Combination of 16S rRNA-targeted oligonucleotide probes with flow cytometry for analyzing mixed microbial populations," Applied and Environmental Microbiology, vol. 56, no. 6, pp. 1919-1925, 1990.

[37] H. Daims, A. Brühl, R. Amann, K. H. Schleifer, and M. Wagner, "The domain-specific probe EUB338 is insufficient for the detection of all bacteria: development and evaluation of a more comprehensive probe set," Systematic and Applied Microbiology, vol. 22, no. 3, pp. 434-444, 1999.

[38] A. Neef, Anwendung der in situ Einzelzell-Identifizierung von Bakterien zur populationsanalyse in komplexen mikrobiellen biozönosen [Ph.D. thesis], Technische Universität München, 1997.

[39] W. Manz, R. Amann, W. Ludwig, M. Wagner, and K. H. Schleifer, "Phylogenetic oligodeoxynucleotide probes for the major subclasses of proteobacteria: problems and solutions," Systematic and Applied Microbiology, vol. 15, no. 4, pp. 593600, 1992. 
[40] R. M. Morris, M. S. Rappé, S. A. Connon et al., "SAR11 clade dominates ocean surface bacterioplankton communities," Nature, vol. 420, no. 6917, pp. 806-810, 2002.

[41] T. Bouvier, P. A. del Giorgio, and J. M. Gasol, "A comparative study of the cytometric characteristics of High and Low nucleic-acid bacterioplankton cells from different aquatic ecosystems," Environmental Microbiology, vol. 9, no. 8, pp. 2050-2066, 2007.

[42] E. M. Smith and P. A. del Giorgio, "Low fractions of active bacteria in natural aquatic communities?" Aquatic Microbial Ecology, vol. 31, no. 2, pp. 203-208, 2003.

[43] P. A. del Giorgio, Y. T. Prairie, and D. F. Bird, "Coupling between rates of bacterial production and the abundance of metabolically active bacteria in lakes, enumerated using CTC reduction and flow cytometry," Microbial Ecology, vol. 34, no. 2, pp. 144-154, 1997.

[44] L. Campbell and D. Vaulot, "Photosynthetic picoplankton community structure in the subtropical North Pacific Ocean near Hawaii (station ALOHA)," Deep-Sea Research Part I, vol. 40, no. 10, pp. 2043-2060, 1993.

[45] P. F. Moreira-Turcq and J. M. Martin, "Characterisation of fine particles by flow cytometry in estuarine and coastal Arctic waters," Journal of Sea Research, vol. 39, no. 3-4, pp. 217-226, 1998.

[46] C. Totti, M. Cangini, C. Ferrari et al., "Phytoplankton sizedistribution and community structure in relation to mucilage occurrence in the Northern Adriatic Sea," Science of the Total Environment, vol. 353, no. 1-3, pp. 204-217, 2005.

[47] F. Cerino, F. Bernardi Aubry, J. Coppola et al., "Spatial and temporal variability of pico-, nano- and microphytoplankton in the offshore waters of the Southern AdriaticSea (Mediterranean Sea)," Continental Shelf Research. In press.

[48] D. Marie, C. P. D. Brussaard, R. Thyrhaug, G. Bratbak, and D. Vaulot, "Enumeration of marine viruses in culture and natural samples by flow cytometry," Applied and Environmental Microbiology, vol. 65, no. 1, pp. 45-52, 1999.

[49] M. J. W. Veldhuis and G. W. Kraay, "Application of flow cytometry in marine phytoplankton research: current applications and future perspectives," Scientia Marina, vol. 64, no. 2, pp. 121-134, 2000.

[50] L. A. Pan, L. H. Zhang, J. Zhang, J. M. Gasol, and M. Chao, "On-board flow cytometric observation of picoplankton community structure in the East China Sea during the fall of different years," FEMS Microbiology Ecology, vol. 52, no. 2, pp. 243-253, 2005.

[51] P. A. del Giorgio, Y. T. Prairie, and D. F. Bird, "Coupling between rates of bacterial production and the abundance of metabolically active bacteria in lakes, enumerated using CTC reduction and flow cytometry," Microbial Ecology, vol. 34, no. 2, pp. 144-154, 1997.

[52] E. M. Smith, "Coherence of microbial respiration rate and cellspecific bacterial activity in a coastal planktonic community," Aquatic Microbial Ecology, vol. 16, no. 1, pp. 27-35, 1998.

[53] H. Eilers, J. Pernthaler, F. O. Glöckner, and R. Amann, "Culturability and in situ abundance of pelagic bacteria from the North Sea," Applied and Environmental Microbiology, vol. 66, no. 7, pp. 3044-3051, 2000.

[54] H. Eilers, J. Pernthaler, and R. Amann, "Succession of pelagic marine bacteria during enrichment: a close look at cultivationinduced shifts," Applied and Environmental Microbiology, vol. 66, no. 11, pp. 4634-4640, 2000.

[55] L. Alonso-Sáez, V. Balagué, E. L. Sà et al., "Seasonality in bacterial diversity in North-West Mediterranean coastal waters: assessment through clone libraries, fingerprinting and FISH," FEMS Microbiology Ecology, vol. 60, no. 1, pp. 98-112, 2007.

[56] R. Amann and B. M. Fuchs, "Single-cell identification in microbial communities by improved fluorescence in situ hybridization techniques," Nature Reviews Microbiology, vol. 6, no. 5, pp. 339-348, 2008.

[57] F. Simonato, P. R. Gómez-Pereira, B. M. Fuchs, and R. Amann, "Bacterioplankton diversity and community composition in the Southern Lagoon of Venice," Systematic and Applied Microbiology, vol. 33, no. 3, pp. 128-138, 2010. 

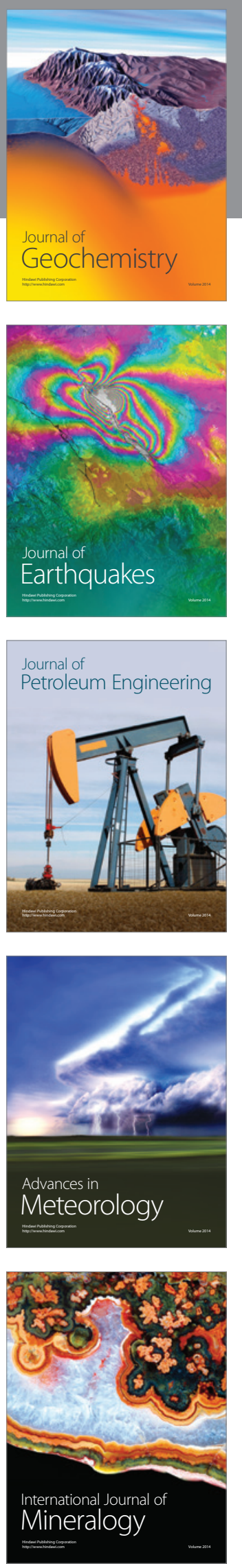
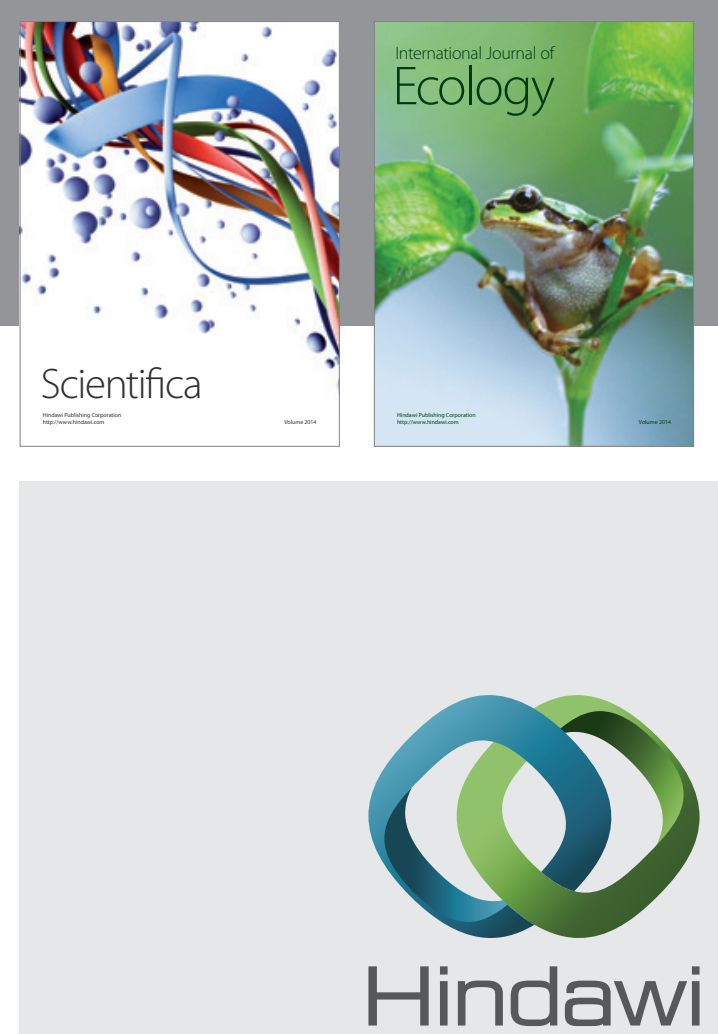

Submit your manuscripts at http://www.hindawi.com
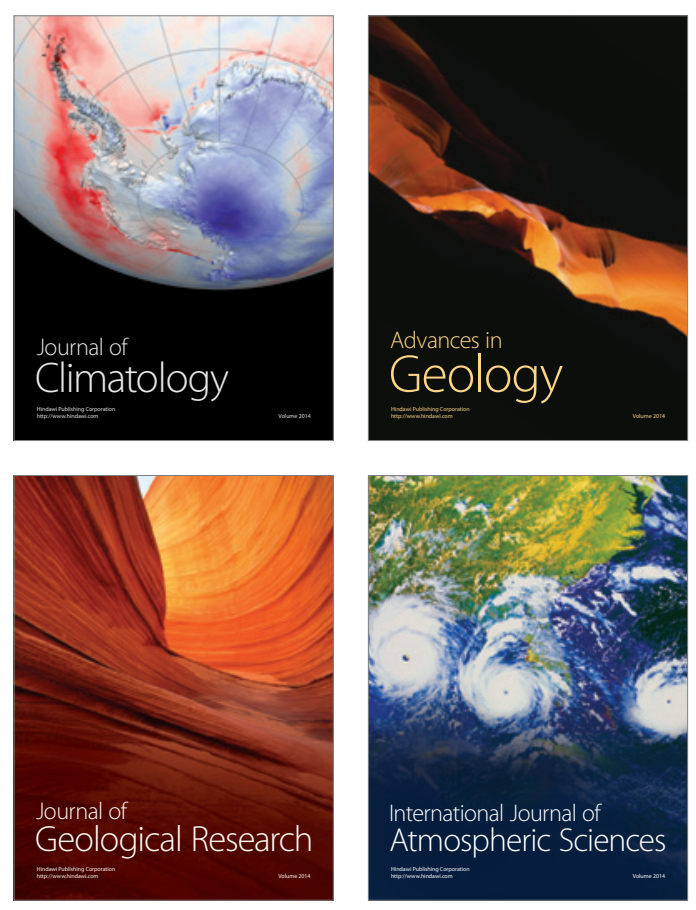
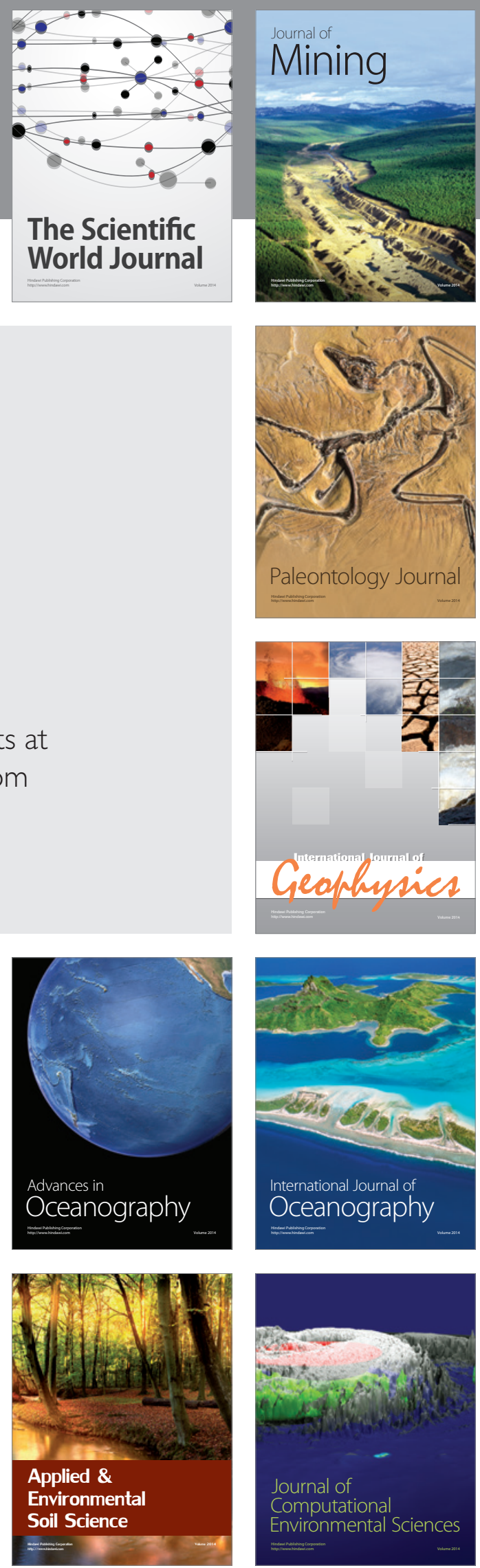